\title{
Fumigation with acetic acid vapor to control decay of stored apples
}

\author{
Peter L. Sholberg ${ }^{\star}$, Margaret Cliff, A. Leigh Moyls
}

\section{Agriculture}

and Agri-Food Canada, Pacific Agri-Food Research Centre, Summerland, British Columbia VOH 1Z0, Canada

\section{CONT \# 2103}

sholbergp@em.agr.ca

\section{* Correspondence and reprints}

Received 29 November 2000 Accepted 25 April 2001

Fruits, 2001, vol. 56, p. 355-366 (C) 2001 Cirad/EDP Sciences All rights reserved

Resumen EsPañol, p. 365

\section{Fumigation with acetic acid vapor to control decay of stored apples.}

Abstract - Introduction. Apples are potentially subject to blue mold decay caused by Penicillium expansum if stored at $1{ }^{\circ} \mathrm{C}$ for three or more months or if wounded during handling. Results from trials with apples contaminated with conidia of $\mathrm{P}$. expansum and fumigated in small chambers with acetic acid (AA) vapor indicated that fruit could be sterilized to reduce decay without effect on fruit quality. The objective of this study was to determine if langer quantities of apples treated with $A A$ vapor would have less decay after storage and/or wounding. It was also important to determine if fumigation would affect apple quality and aroma. Materials and methods. Apple cultivars were harvested at commercial maturity for use in AA fumigation trials. Apples artificially or naturally contaminated with conidia of $\mathrm{P}$. expansum were fumigated with AA vapor in a $1 \mathrm{~m}^{3}$ gas tight chamber at $10^{\circ} \mathrm{C}$ for $1 \mathrm{~h}$ to $24 \mathrm{~h}$ or dipped in $450 \mu \mathrm{g}$ thiabendazole $\times \mathrm{L}^{-1}$ solution. Fruit fumigated in standard wooden or plastic apple boxes, or small wooden bins were either wounded and evaluated for decay after a week at $20^{\circ} \mathrm{C}$ or stored at $1{ }^{\circ} \mathrm{C}$ for three or more months and evaluated for decay. Then apple quality was assessed. Results. Apples naturally contaminated with Penicillium spp. that had been stored at $1^{\circ} \mathrm{C}$ in air storage and treated with AA vapour had $50 \%$ less decay than the control fruit. In another experiment, AA fumigation was as effective as thiabendazole in reducing decay. AA fumigation reduced decay of fruit coming out of storage for apples stored for 3 months, and a second AA fumigation reduced infection of wounds on these same apples. AA fumigation before storage did not affect apple quality or vinegar aroma. Discussion. AA fumigation showed great potential for reducing decay in stored apples. It could be used as an organic alternative to synthetic fungicides for control of blue mold decay.

Canada / Malus (fruits) / postharvest decay / fungal diseases / Penicillium ex pansum / disease control / control methods / fumigation / acetic acid / thiabendazole / quality

\section{Contrôle de la détérioration des pommes stockées par traitement à la vapeur d'acide acétique.}

Résumé - Introduction. Les pommes sont potentiellement sujettes à la moisissure bleue provoquée par Penicillium expansum si elles sont stockées à $1{ }^{\circ} \mathrm{C}$ pendant 3 mois ou plus, ou si elles sont blessées pendant la manutention. Les résultats d'essais effectués avec des pommes contaminées par des conidies de P. expansum et fumigées dans un local restreint avec de la vapeur d'acide acétique (AA) ont montré que les fruits stérilisés pouvaient être moins détériorés, sans que leur qualité ne soit altérée. L'objectif de cette étude a été de déterminer s'il était possible de protéger de plus grandes quantités de pommes contre ces détériorations après stockage et/ou après blessures en les traitant à la vapeur de AA. Il s'agissait également de déterminer si la fumigation affectait la qualité et l'arôme des pommes traitées. Matériel et méthodes. Des pommes de différents cultivars ont été récoltées au stade de maturité commerciale puis elles ont été artificiellement ou naturellement contaminées avec des conidies de $\mathrm{P}$. expansum. Elles ont été alors fumigées avec de la vapeur de AA dans une une chambre de $1 \mathrm{~m}^{3}$, étanche au gaz, à $10^{\circ} \mathrm{C}$ pendant $1 \mathrm{~h}$ à $24 \mathrm{~h}$ ou plongées dans une solution à $450 \mu \mathrm{g}$ thiabendazole $\times \mathrm{L}^{-1}$. Les fruits fumigés ont été soit blessés puis évalués vis-à-vis de leur détérioration après 1 semaine à $20^{\circ} \mathrm{C}$, soit stockés à $1{ }^{\circ} \mathrm{C}$ pendant 3 mois ou plus puis évalués quant à leur état. La qualité des pommes a alors été estimée. Résultats. Les pommes naturellement contaminées avec Penicillium spp., stockées à l'air à $1{ }^{\circ} \mathrm{C}$ et traitées à la vapeur de AA ont été moitié moins détériorées que les fruits témoins. Dans une autre expérimentation, la fumigation avec AA a été aussi efficace que le thiabendazole pour réduire la moisissure. La fumigation avec AA a réduit la détérioration des fruits après stockage pendant 3 mois, et un deuxième traitement à AA a diminué l'infection des blessures sur ces mêmes pommes. La fumigation avec AA effectuée avant stockage n'a pas affecté la qualité des pommes ni leur arôme. Discussion. Les fumigations à la vapeur de AA sont donc potentiellement très intéressantes pour réduire la détérioration des pommes stockées. Elles pourraient remplacer les fongicides synthétiques pour le contrôle de la moisissure bleue de la pomme.

Canada / Malus (fruits) / maladie post récolte / maladie fongique / Penicillium ex pansum / contrôle de maladies / méthode de lutte / fumigation / acide acétique / thiabendazole / qualité 


\section{Introduction}

The Okanagan and associated valleys within British Columbia, Canada, produce approximately $50 \%$ of the Canadian apple crop of which approximately one half is stored for three or more months. Fruit stored in air or controlled atmosphere (CA) storage at temperatures at or near $0{ }^{\circ} \mathrm{C}$ are subject to decay by fungi such as Penicillium expansum and Botrytis cinerea [1, 2]. The use of synthetic fungicides is frowned upon because of the concern that they are carcinogenic and harmful to the environment. Packinghouse managers would rather not use fungicides because residues on the fruit could be associated with health hazards such as cancer [3]. Furthermore, organic growers are not allowed to use synthetic fungicides and growers who produce apples for baby food processors must rely on preharvest decay control strategies.

Penicillium expansum, also known as blue mold, is the most important causal agent of apple decay in Canada [4] and the United States [5]. Control of blue mold relies on the integration of several practices including selection of apple cultivars resistant to decay, harvesting fruit with optimal maturity, handling to avoid bruising and injury, bin and packinghouse sanitation, and use of fungicides or biologicals to control blue mold. In Canada and the United States, the only fungicide acceptable by the fruit industry for postharvest use on apples is thiabendazole although P. expansum has developed resistance to it [6]. For the above reasons, an acceptable alternative to thiabendazole is required for control of decay in stored apples.

Alternatives to synthetic fungicides that need further study as possible treatments to control postharvest decay are fumigants. Fumigation is not widely used as a method of controlling postharvest decay although fumigants have some particularly useful properties. Fumigants can diffuse through space and penetrate into protected places that are inaccessible to liquid or solid pesticides, and exert their effect during the exposure period but diffuse away afterwards leaving little or no residue [7]. The only commercial crop fumigated to prevent decay are table grapes. Sulfur dioxide fumigation is primarily used to prevent the contact spread of Botrytis cinerea on table grapes during storage [8].

Use of acetaldehyde vapor to control postharvest pathogens has been investigated in apples [9], cherries [10] and oranges [11]. Acetaldehyde was effective but phytotoxic on cherries and oranges. Stadelbacher and Prasad [9] showed that decay of apples inoculated with P. expansum was prevented by acetaldehyde fumigation at concentrations as low as $0.5 \%(\mathrm{v} / \mathrm{v})$ for $180 \mathrm{~min}$, or $3 \%$ for $30 \mathrm{~min}$. As far as we are aware, this treatment has not been tried in commercial storages probably because of concerns with flammability and carcinogenicity. On the other hand, acetic acid (AA) in air at low concentrations is not flammable, explosive, or carcinogenic [12] and is very effective against molds such as P. expansum that cause storage decay [13]. Subsequent studies showed that AA fumigation would control postharvest decay caused by other pathogens such as Monilinia fructicola and Botrytis cinerea on apricots [14], cherries [15, 16], citrus [16], grapes [17], peaches [14], nectarines [14] and strawberries [18]. Acetic acid vapor treatment for the control of postharvest decay has been reviewed [19] identifying additional uses in food processing and modified atmosphere packaging.

The objective of this study was to determine if relatively lange quantities of apples treated with acetic acid vapor would have less decay after storage and/ or after wounding. Fumigation parameters such as acetic acid rate, duration of fumigation, and type of container used during fumigation were assessed as well as apple quality, storage disorders and vinegar aroma.

\section{Materials and methods}

All apples used in this study were harvested at commercial maturity from an orchard located at the Pacific Agri-Food Research Centre (PARC), Summerland, British Columbia, Canada, and placed in $(1.0 \pm 0.2){ }^{\circ} \mathrm{C}$ cold storage until needed. All fumigation 
trials were done at least three times with laboratory grade glacial acetic acid (AA) in a $1 \mathrm{~m}^{3}$ fumigation chamber as previously described [17] at $10{ }^{\circ} \mathrm{C}$, on fruit that had been stored at $10^{\circ} \mathrm{C}$ for at least $16 \mathrm{~h}$ prior to fumigation.

\subsection{Apple sanitation study}

'Gala', 'McIntosh', 'Delicious' (Golden and Red), 'Jonagold', and 'Spartan' apples stored for (7 to 8) months in air were used in this study. Sixteen $\mathrm{kg}$ of each apple cultivar were placed in small wooden bins $(27.5 \mathrm{~cm}$ high by $48 \mathrm{~cm}$ wide by $61 \mathrm{~cm}$ long), $1 / 20^{\text {th }}$ the size of standard apple bins. Three of these model bins with each bin filled with $16 \mathrm{~kg}$ of apples of a particular cultivar were fumigated with $10 \mu \mathrm{L}$ glacial acetic acid $\times \mathrm{L}^{-1}$ vapor. After fumigation for either (1, 1.5, 2 or 24$) \mathrm{h}$, the chamber was opened and allowed to vent for at least $30 \mathrm{~min}$.

Both fumigated and control fruit were subsampled by taking 30 apples from each model bin replicate, punctured at three locations on each fruit with a $5 \mathrm{~cm}$ finishing nail that protruded $6 \mathrm{~mm}$ from a cork stopper. The protruding end of the nail was kept sterile by dipping in 95\% ethanol and flaming after wounding 10 apples. The apples were placed at $(20 \pm 1){ }^{\circ} \mathrm{C}$ for 1 week and the number of punctures that decayed were recorded. The experiment was repeated three times.

Analysis of variance was applied to the arcsine-transformed cultivar data with the General Linear Model (GLM) procedure (SAS Institute, Cary, NC) and following a significant $F$ test $(P \geq 0.05)$ means were separated with Duncan's Multiple Range Test $(P=0.05)$.

\subsection{Bagged apple study}

'Spartan' apples were segregated into lots based upon treatment, inoculation with Peniciliium expansum, and whether punctured with a sterile nail. The apples were inoculated by misting with a $6.2 \times 10^{4}$ colonyforming units $(\mathrm{CFU}) \times \mathrm{mL}^{-1}$ conidial suspension of $\mathrm{P}$. expansum counted with a haemacytometer, and then punctured as described above. The fruit were fumigated with $7.5 \mu \mathrm{L}$ glacial acetic acid $\times \mathrm{L}^{-1}$ as described previously. After venting the remaining acetic acid vapor, the fruit was placed in plastic packing bags with ventilation holes (1.5 kg fruit). The bagged apples were stored at $(5.0 \pm 0.2){ }^{\circ} \mathrm{C}$ for $30 \mathrm{~d}$ followed by $7 \mathrm{~d}$ at $(20 \pm 1){ }^{\circ} \mathrm{C}$, when the numbers of decayed fruit were recorded. Each treatment factor was replicated four times. The data were analyzed as a triple factorial experiment with the GLM procedure of SAS (SAS Institute, Cary, NC).

In a second trial, 'McIntosh' and 'Delicious (Red)' apples were used. Acetic acid fumigation $\left(7.5 \mu \mathrm{L} \times \mathrm{L}^{-1}\right)$ was compared with the standard postharvest fungicide treatment of thiabendazole. The apples were fumigated or dipped for $1 \mathrm{~min}$ in a $450 \mu \mathrm{L}$ thiabendazole $\times \mathrm{L}^{-1}$ solution (Merteck $45 \%$ flowable, Montreal, Quebec, Canada). Following treatment, the apples were bagged and stored at $(20 \pm 1){ }^{\circ} \mathrm{C}$ for $21 \mathrm{~d}$, and the number of decayed apples were recorded. Analysis of variance was applied to the arcsine-transformed data with the GLM procedure (SAS Institute, Cary, NC) and means were separated with Duncan's Multiple Range Test $(P=0.05)$.

\subsection{Long term apple storage study}

The effect of AA fumigation on stored apples was studied in three trials. In a first trial, $10 \mathrm{~kg}$ of Red 'Delicious', Golden 'Delicious' and 'Spartan' apples were placed into plastic boxes, inoculated by misting with $1 \times 10^{6} \mathrm{CFU}$ P. expansum $\times \mathrm{mL}^{-1}$, allowed to dry and dipped for $0.5 \mathrm{~min}$ in $450 \mu \mathrm{L}$ thiabendazole $\times \mathrm{L}^{-1}$ or fumigated with $7.5 \mu \mathrm{L}$ acetic acid $\times \mathrm{L}^{-1}$. Apples were stored at $(1 \pm 0.2){ }^{\circ} \mathrm{C}$ for 3 months, removed from storage and a subsample of 15 fruits from each replicate was punctured as described above, placed at $(20 \pm 1){ }^{\circ} \mathrm{C}$ for 1 week, and the number of decayed punctures were recorded. Analysis of variance was applied to the arcsine-transformed data with the GLM procedure (SAS Institute, Cary, NC) and means were separated with Duncan's Multiple Range Test $(\mathrm{P}=0.05)$.

In a second experiment, 'McIntosh' apples received multiple fumigations to test 
their effect on apple quality. Apples were fumigated from one to eight times starting immediately after the fruit was placed in cold storage at $(1 \pm 0.2){ }^{\circ} \mathrm{C}$ for $111 \mathrm{~d}$. Physiological disorders such as lenticel injury and scald were visually assessed on fruit from storage after a ripening period of $7 \mathrm{~d}$ at $20{ }^{\circ} \mathrm{C}$.

A third trial was conducted in two parts, with apple quality and aroma evaluated in the first part, and decay in the second part.

In the quality and aroma trial, $14 \mathrm{~kg}$ of 'Gala', 'Jonagold' and 'Spartan' apples were placed in model bins, interlocking plastic apple boxes $(25 \mathrm{~cm} \times 30 \mathrm{~cm} \times 45 \mathrm{~cm})$ and standard wooden apple boxes $(30 \mathrm{~cm} \times 30 \mathrm{~cm} \times 45 \mathrm{~cm})$. Fruit stacked three boxes high were fumigated for $24 \mathrm{~h}$ with $9.0 \mu \mathrm{L} \mathrm{AA} \times \mathrm{L}^{-1}$. After venting for $1 \mathrm{~h}$ to $2 \mathrm{~h}$, apples were stored at $(1 \pm 0.2){ }^{\circ} \mathrm{C}$ for $90 \mathrm{~d}$. Upon removal from storage, subsamples of ten and six 'Gala' apples were taken for quality and aroma tests, respectively. Lenticel burning was visually assessed. Soluble solids and titratable acidity were determined by juicing each apple and measuring percent soluble solids with an Abbé refractometer (AO instruments, Buffalo, NY), and titratable acidity with a Brinkmann Titroprocessor ensemble (Metrohm, Herisau, Switzerland). Analysis of variance was applied to the arcsine-transformed data with the GLM procedure (SAS Institute, Cary, $\mathrm{NC}$ ) and means were separated with Duncan's Multiple Range Test $(\mathrm{P}=0.05)$.

The aroma of acetic acid can be described as a vinegar aroma. Therefore, vinegar aroma was evaluated by a panel of 16 subjects (employees of Agriculture and AgriFood Canada). They evaluated both whole and sliced apples from the six treatments from storage, and a freshly fumigated treatment done $16 \mathrm{~h}$ prior to sensory evaluation. A random sample of six apples was obtained from treated and nontreated 'Gala' apples. For the whole apples, four apples were placed in $2 \mathrm{~L}$ plastic buckets with removable plastic lids. For the sliced apples, two apple slices from each treatment were placed in $250 \mathrm{~mL}$ glasses and covered with plastic lids. Samples were left at room temperature overnight and assessed the following morning with half the panelists evaluating the whole apples first and half evaluating the sliced apples first.

Subjects lifted the lids of the sample containers and sniffed the samples in random order indicating the presence or absence of perceived acetic acid/vinegar aroma. Responses were tabulated and recorded and significance of responses analyzed statistically by the method of Csima and Reid [20].

The second part of the trial evaluated decay. Apples were stored for 4 months at $(1.0 \pm 0.2){ }^{\circ} \mathrm{C}$ before they were used. Fruit in plastic and wooden boxes were fumigated with $7.0 \mu \mathrm{L} \mathrm{AA} \times \mathrm{L}^{-1}$ while the larger model bins were fumigated with $8.0 \mu \mathrm{L}$ AA $\times \mathrm{L}^{-1}$ before and after storage for $90 \mathrm{~d}$. Decay was evaluated by recording the total number of decayed fruit after storage. Fifteen fruit were subsampled after the final AA fumigation. The number of decayed punctures was recorded after $6 \mathrm{~d}$ at $(20 \pm 1){ }^{\circ} \mathrm{C}$. The arcsine-transformed data were analyzed as a double factorial experiment with treatment and boxes as main effects with the GLM procedure of SAS (SAS Institute, Cary, NC) and means were separated with Duncan's Multiple Range Test $(\mathrm{P}=0.05)$.

\section{Results}

\subsection{Apple sanitation}

Fumigation with $10 \mu \mathrm{LAA} \times \mathrm{L}^{-1}$ reduced the percentage of decayed punctures in 'Gala', 'McIntosh', Golden 'Delicious', Red 'Delicious', and 'Spartan' apples after (7 to 8) months of storage at $1{ }^{\circ} \mathrm{C}$ (table I). Extending the fumigation duration from (1 to 24$) \mathrm{h}$ did not improve decay control significantly.

\subsection{Bagged apples}

Fumigation with $7.5 \mu \mathrm{L} \mathrm{AA} \times \mathrm{L}^{-1}$ significantly reduced the number of 'Spartan' apples that decayed in bags stored at $5{ }^{\circ} \mathrm{C}$ for $30 \mathrm{~d}$ (table II). In a shelf life trial with 
'McIntosh' apples where thiabendazole postharvest treatment was compared with AA fumigation, only AA fumigation was effective in reducing decay (table III).

\subsection{Long term apple storage}

Fumigation with $7.5 \mu \mathrm{L} \mathrm{AA} \times \mathrm{L}^{-1}$ reduced the percent of 'Spartan' apples that decayed

\section{Table I.}

Effect of acetic acid fumigation in preventing decay in wounded apples.

\begin{tabular}{|c|c|c|c|}
\hline Apple cultivar & Treatment $^{1}$ & Treatment duration (h) & $\%$ decay \\
\hline Gala & $\begin{array}{c}\text { Control } \\
\text { Acetic acid }\end{array}$ & $\begin{array}{l}0.0 \\
2.0\end{array}$ & $\begin{array}{r}80.9 \mathrm{a} \\
1.1 \mathrm{~b}\end{array}$ \\
\hline Mclntosh & $\begin{array}{c}\text { Control } \\
\text { Acetic acid }\end{array}$ & $\begin{array}{l}0.0 \\
1.0\end{array}$ & $\begin{array}{l}77.8 \mathrm{a} \\
10.3 \mathrm{~b}\end{array}$ \\
\hline Golden Delicious & $\begin{array}{c}\text { Control } \\
\text { Acetic acid } \\
\text { Acetic acid }\end{array}$ & $\begin{array}{r}0.0 \\
1.5 \\
24.0\end{array}$ & $\begin{array}{r}61.5 \mathrm{a} \\
6.2 \mathrm{~b} \\
2.3 \mathrm{~b}\end{array}$ \\
\hline Jonagold & $\begin{array}{c}\text { Control } \\
\text { Acetic acid } \\
\text { Acetic acid }\end{array}$ & $\begin{array}{l}0.0 \\
1.5 \\
2.0\end{array}$ & $\begin{array}{r}48.5 \mathrm{a} \\
2.9 \mathrm{~b} \\
5.8 \mathrm{~b}\end{array}$ \\
\hline Red Delicious & $\begin{array}{c}\text { Control } \\
\text { Acetic acid } \\
\text { Acetic acid } \\
\text { Acetic acid }\end{array}$ & $\begin{array}{r}0.0 \\
1.0 \\
2.0 \\
24.0\end{array}$ & $\begin{array}{r}54.8 \mathrm{a} \\
1.7 \mathrm{~b} \\
1.1 \mathrm{~b} \\
1.7 \mathrm{~b}\end{array}$ \\
\hline Spartan & $\begin{array}{c}\text { Control } \\
\text { Acetic acid } \\
\text { Acetic acid } \\
\text { Acetic acid }\end{array}$ & $\begin{array}{r}0.0 \\
1.0 \\
2.0 \\
24.0\end{array}$ & $\begin{array}{r}69.9 \mathrm{a} \\
5.2 \mathrm{~b} \\
1.7 \mathrm{~b} \\
4.4 \mathrm{~b}\end{array}$ \\
\hline
\end{tabular}

\section{Table II.}

Effect of acetic acid fumigation on bagged 'Spartan' apples.

\begin{tabular}{|c|c|c|c|}
\hline \multirow[t]{2}{*}{ Treatment ${ }^{1}$} & \multicolumn{3}{|c|}{$\%$ decayed fruit in } \\
\hline & untreated fruit & inoculated fruit $^{2}$ & punctured fruit \\
\hline Control & 9.4 & 17.0 & 50.9 \\
\hline Acetic acid & $4.2^{\star *}$ & $14.6^{\star \star \star \star}$ & $35.7^{* \star \star \star}$ \\
\hline
\end{tabular}




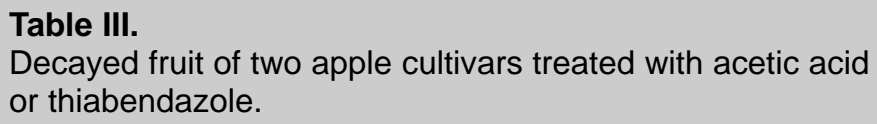

\begin{tabular}{lrc} 
Treatment & \multicolumn{2}{c}{ Decayed fruit (\%) in } \\
\cline { 2 - 3 } & Mclntosh & Red Delicious \\
& & \\
Control & $38.8 \mathrm{a}$ & 8.1 \\
Acetic acid & $4.1 \mathrm{~b}$ & 5.0 \\
Thiabendazole & $59.9 \mathrm{a}$ & 5.1
\end{tabular}

${ }^{1}$ Apples were stored for 5 months at $1{ }^{\circ} \mathrm{C}$, treated with $7.5 \mu \mathrm{L}$ acetic acid $\times \mathrm{L}^{-1}$ or $450 \mu \mathrm{g}$ thiabendazole $\times \mathrm{L}^{-1}$, placed at $20{ }^{\circ} \mathrm{C}$ for $21 \mathrm{~d}$, and the number of decayed apples recorded.

Means followed by the same letter in a column are not significantly different according to Duncan's Multiple Range Test $(P=0.05)$.

\section{Figure 1.}

Percent of apples decayed that were treated with $7.5 \mu \mathrm{L}$ glacial acetic acid $\times \mathrm{L}^{-1}$ or dipped for $0.5 \mathrm{~min}$ in $450 \mu \mathrm{g}$ thiabendazole $\times \mathrm{L}^{-1}$ and stored for 3 months at $1{ }^{\circ} \mathrm{C}$. Means were separated with the Duncan's Multiple Range Test $(P=0.05)$.

\section{Figure 2.}

Percent wounds (nail punctures) that decayed in apples from storage for $102 \mathrm{~d}$ at $1{ }^{\circ} \mathrm{C}$ that were treated by acetic acid fumigation $\left(7.5 \mu \mathrm{L} \times \mathrm{L}^{-1}\right)$ or dipping for $0.5 \mathrm{~min}$ in $450 \mu \mathrm{g}$ thiabendazole $\times \mathrm{L}^{-1}$. Prior to storage, the apples had been inoculated with Penicillium expansum, and treated with $7.5 \mu \mathrm{L}$ glacial acetic acid $\times \mathrm{L}^{-1}$ or dipped for $1 \mathrm{~min}$ in a $450 \mu \mathrm{g}$ thiabendazole $\times \mathrm{L}^{-1}$ solution. Means were separated with the Duncan's Multiple Range Test $(P=0.05)$.
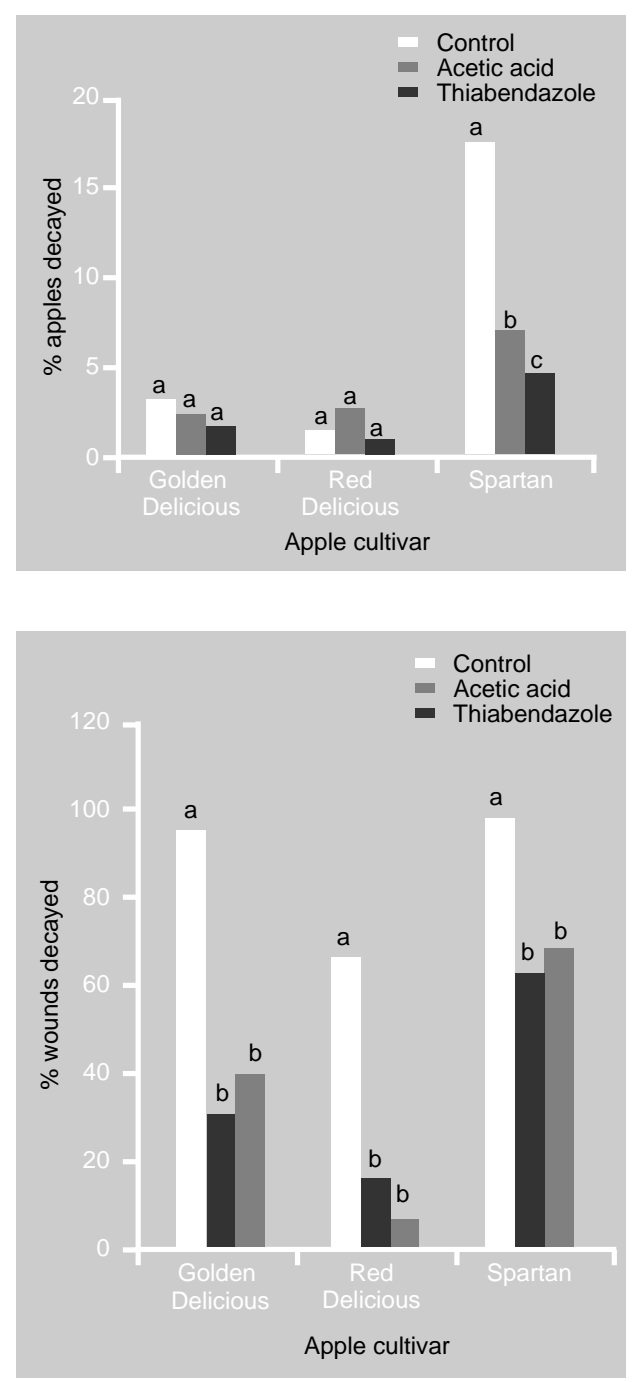

overstorage for 3 months at $1{ }^{\circ} \mathrm{C}$ and 1 week at $20^{\circ} \mathrm{C}$ (figure 1 ). If the apples were punctured, AA fumigation reduced the percent of decay in Golden 'Delicious', Red 'Delicious' and 'Spartan' apples and was just as affective as thiabendazole (figure 2).

Damage to the fruit skin caused by multiple AA fumigations was studied in 'McIntosh' apples stored for $111 \mathrm{~d}$. Lenticel damage increased tremendously with four to eight fumigations (table IV). Scald, another important disonder of stored apples, was not affected by AA fumigation.

The effect of one fumigation with $9.0 \mu \mathrm{LAA}$ $\times \mathrm{L}^{-1}$ was studied in more detail in subsequent experiments. After $90 \mathrm{~d}$ storage, significant lenticel damage was found in AA fumigated 'Gala' and 'Spartan' apples (table V). AA fumigation did not affect percent soluble solids or titratable acidity. The type of container used for AA fumigation influenced the percent of fruit with lenticel damage (table VI), with the plastic box corresponding to higher lenticel damage for 'Gala' apples. The model wooden bin had the lowest levels of lenticel damage for 'Spartan' apples.

'Gala' apples from the above trial had no detectable acetic/vinegar aroma in treated whole apples that had been stored for $90 \mathrm{~d}$, although all the subjects detected vinegar aroma in 'freshly' fumigated apples. The results were almost the same for sliced apples except that only $19 \%$ of the subjects could detect the vinegar aroma in the 'freshly' fumigated apple slices.

Fumigation of naturally contaminated fruit with $7.0 \mu \mathrm{L} \mathrm{AA} \times \mathrm{L}^{-1}$ reduced decay in 'Jonagold' apples by approximately one half compared with the untreated control after the fruit had been fumigated and stored for $90 \mathrm{~d}$ (table VII). The use of AA fumigation immediately before injuring fruit after storage reduced the number of punctures that decayed from $32 \%$ to $6 \%$ in 'Gala' and $32 \%$ to $12 \%$ in 'Jonagold'. Analysis of the data indicated that there was a significant container effect on decay in 'Gala' and 'Jonagold' apples (table VII). Fewer decayed punctures occurred in 'Jonagold' apples that were fumigated in the model bin or wooden apple box (table VIII). In 'Gala', the lowest percentage of decayed punctures was in 
fruit fumigated in the model bin. Container type had no effect on decay of 'Spartan' apples.

\section{Discussion}

AA fumigation shows great potential for reducing postharvest decay on apples stored under conditions that are similar to those used in commercial storage. The treatment is very effective when it is used to sterilize the surface of the fruit preventing decay. Results showed that AA fumigation reduced decay in apple punctures to insignificant levels in 'Gala', 'Jonagold', Red 'Delicious', and 'Spartan' apple cultivars (table I). The higher-than-usual decay level

\begin{tabular}{|c|c|c|c|}
\hline Timing & Frequency & $\%$ lenticel damage & $\%$ scald \\
\hline None & 0 & $5.3 \mathrm{~b}$ & 91.8 \\
\hline Prior to storage & 1 & $5.3 b$ & 67.5 \\
\hline Once per month & 4 & $39.9 \mathrm{a}$ & 96.5 \\
\hline Twice per month & 8 & $45.2 \mathrm{a}$ & 96.5 \\
\hline
\end{tabular}

\section{Table V.}

Effect of acetic acid fumigation $\left(9.0 \mu \mathrm{L} \times \mathrm{L}^{-1}\right)$ on quality of apples stored for $90 \mathrm{~d}$ at $1{ }^{\circ} \mathrm{C}$ in three container types.

\begin{tabular}{|c|c|c|c|c|}
\hline Apple cultivar & Treatment & $\%$ lenticel damage & \% soluble solids & Titratable acidity \\
\hline \multirow[t]{2}{*}{ Gala } & Control & 8.3 & 12.87 & 6.64 \\
\hline & Acetic acid & 25.8 & 12.85 & 6.90 \\
\hline \multicolumn{5}{|l|}{ Significance: } \\
\hline Treatment & & ** & ns & ns \\
\hline Container & & ** & ns & ns \\
\hline Treatment $\times$ container & & $* *$ & * & ns \\
\hline \multirow[t]{2}{*}{ Jonagold } & Control & 3.2 & 13.27 & 8.28 \\
\hline & Acetic acid & 45.6 & 13.07 & 8.29 \\
\hline \multicolumn{5}{|l|}{ Significance: } \\
\hline Treatment & & ns & ns & ns \\
\hline Container & & ns & ns & ns \\
\hline Treatment $\times$ container & & ns & ns & ns \\
\hline \multirow[t]{2}{*}{ Spartan } & Control & 3.2 & 13.40 & 8.18 \\
\hline & Acetic acid & 28.9 & 13.48 & 7.80 \\
\hline \multicolumn{5}{|l|}{ Significance: } \\
\hline Treatment & & *** & ns & ns \\
\hline Container & & ** & ns & ns \\
\hline Treatment $\times$ container & & * & ns & ns \\
\hline
\end{tabular}


of $10 \%$ in AA fumigated 'McIntosh' apples likely was the result of a heavy spore load on the fruit. Sholberg and Gaunce [13] showed that, as the inoculum concentration of P. expansum conidia increased, the degree of control decreased if the AA concentration remained constant.
In some trials, apples were inoculated with P. expansum and artificially wounded by puncturing with a nail to insure decay. These trials showed that AA fumigation was just as effective as thiabendazole in preventing decay on fruit inoculated with P. expansum. In one particular trial,

Table VI.

Effect of container type on percent lenticel damage of apples stored for $90 \mathrm{~d}$ at $1^{\circ} \mathrm{C}$.

\begin{tabular}{lrrr} 
Container type & \multicolumn{3}{c}{$\%$ lenticel damage in apple cultivar } \\
& Gala & Jonagold & Spartan \\
Wooden apple box & $10.7 \mathrm{a}$ & $3.6 \mathrm{a}$ & $19.6 \mathrm{~b}$ \\
Model wooden bin & $5.1 \mathrm{a}$ & $7.2 \mathrm{a}$ & $3.6 \mathrm{a}$ \\
Plastic apple box & $62.6 \mathrm{~b}$ & $24.3 \mathrm{a}$ & $20.5 \mathrm{~b}$
\end{tabular}

Means within columns followed by the same letter are not significantly different according to Duncan's Multiple Range Test $(P=0.05)$.

Table VII.

Effect of acetic acid fumigation $\left(7.0 \mu \mathrm{L} \times \mathrm{L}^{-1}\right)$ before and after storage on decay of apples stored for $90 \mathrm{~d}$ at $1^{\circ} \mathrm{C}$ in three container types.

\begin{tabular}{lccc}
\hline Apple cultivar & Treatment & \% decayed apples & \% decayed wounds \\
Gala & Control & 4.2 & 32.3 \\
& Acetic acid & 2.7 & 5.8 \\
Significance: & & & \\
Treatment & & $\mathrm{ns}$ & $*$ \\
Container & $\mathrm{ns}$ & $\mathrm{ns}$ \\
Treatment $\times$ container & & $\mathrm{ns}$ & 31.9 \\
& & & 12.4 \\
Jonagold & Control & 21.1 & \\
& Acetic acid & 11.1 & $*$ \\
Significance: & & & $*$ \\
Treatment & & $*$ & $\mathrm{~ns}$ \\
Container & & $\mathrm{ns}$ & 62.4 \\
Treatment $\times$ container & & $*$ & 40.9 \\
Spartan & Control & 34.2 & $\mathrm{~ns}$ \\
& Acetic acid & 28.0 & $\mathrm{~ns}$ \\
Significance: & & $\mathrm{ns}$ \\
Treatment & & $\mathrm{ns}$ & \\
Container & & $\mathrm{ns}$ &
\end{tabular}

Apples were stored for 4 months in air at $1{ }^{\circ} \mathrm{C}$ before the start of the trial. ${ }^{\star},{ }^{* \star *}$, ns: significant at $P \leq 0.1, P \leq 0.01$, or not significant, respectively. 


\begin{tabular}{|c|c|c|c|}
\hline \multirow[t]{2}{*}{ Container type } & \multicolumn{3}{|c|}{$\%$ decayed wounds in apple cultivar } \\
\hline & Gala & Jonagold & Spartan \\
\hline Wooden apple box & $16.8 \mathrm{ab}$ & $14.3 \mathrm{~b}$ & $56.8 \mathrm{a}$ \\
\hline Model wooden bin & $9.6 \mathrm{~b}$ & $12.0 \mathrm{~b}$ & $46.6 \mathrm{a}$ \\
\hline Plastic apple box & $26.0 \mathrm{a}$ & $41.3 \mathrm{a}$ & $51.6 \mathrm{a}$ \\
\hline
\end{tabular}

AA fumigation was much more effective than thiabendazole on 'McIntosh' apples (table III). The reason that thiabendazole did not control decay could have been fungicide resistance as reported in New York [21], Washington [22] and Oregon [23] and in British Columbia, Canada [4].

AA fumigation was effective in reducing decay in relatively large volumes of fruit stored for long periods of time. The source of inoculum did not change the effectiveness of AA fumigation. For example, decay was reduced in both 'Spartan' apples inoculated with P. expansum conidia and 'Jonagold' apples naturally contaminated by P. expansum.

Four or more fumigations with AA caused lenticel damage in 'McIntosh' apples (table IV). Previous research had indicated that phytotoxicity caused by AA vapor could be an important problem. For example, Sholberg [16] had shown that AA fumigation could cause pitting of Bing cherries and Sholberg and Gaunce [14] showed that AA fumigation would cause browning on peaches if the AA concentration was not carefully controlled. In these apple trials, two AA fumigations appeared to be safe if they were below $8.0 \mu \mathrm{LAA} \times \mathrm{L}^{-1}$. However, after numerous AA trials on apples, it has become apparent that decay control and lenticel burning and blackening vary with frequency of fumigation treatment, AA concentration, fruit quantity, container type, and apple cultivar. Previous trials in small chambers demonstrated that humidity, temperature, and duration of AA fumigation affect decay control [11].

AA fumigation requires constant monitoring if lenticel burning is to be avoided. Early attempts at monitoring AA concentration during fumigation relied on Kitagawa precision detector tubes (Matheson Safety Products, East Rutherford, NJ) [17]. A sample of acetic acid vapor was drawn into the tube reacting with sodium hydroxide and resulting in a proportional color change that was read in parts per million. This method, although useful for indicating the presence of AA vapor, was found to be costly and inaccurate for AA fumigation. Recent attempts at monitoring AA fumigation have relied on the use of a gas chromatograph and/or solid state sensors [24].

A question that must be answered before acetic acid can be used commercially is if it can be detected in fruit by taste or smell. Vinegar aroma was not detected in AA fumigated 'Gala' apples, suggesting that lenticel burning is the only major quality concern with AA fumigation of apples.

In this study, corrosion of metal by AA fumigation was minimal because use rates were very low and most fumigations were restricted to short durations before and after the fruit had been stored. There was no indication of damage to metal bin parts such as nails; however, after 50 or more fumigations damage began to show on the metal fan impeller used for air circulation in the $1 \mathrm{~m}^{3}$ chamber. The rest of the chamber that was lined with aluminum foil did 
not show any sign of corrosion. Acetic acid will eventually corrode steel and copper parts that are not protected by an acidresistant coating.

Use of AA fumigation is a viable option or complement to the use of other postharvest treatments such as thiabendazole or sodium hypochlorite for control of postharvest decay in stored apples. AA fumigation is suited for use on apples destined for processing and/or where an organic alternative to synthetic fungicides is required. AA fumigation meets these requirements because processing fruit usually have a high potential for decay, acetic acid is relatively cheap, and the fruit may be fumigated without removal from the bins. Another important consideration for using AA fumigation is the concern with patulin in processed juice products such as apple juice [25]. Timely use of AA fumigation will reduce the incidence of Penicillium spp. infection to minimal levels and thus curtail any production of patulin by the fungus.

In conclusion, AA fumigation before and after storage reduces decay and the potential for decay in wounded fruit. If used at rates previously determined by careful experimentation, in consideration of cultivar, temperature, volume of fruit, and container type, AA will not damage fruit lenticels or have any deleterious effect on quality or aroma.

\section{Acknowledgements}

We acknowledge the important contributions of Drs. Alan Gaunce and Michael Meheriuk that have helped to make these trials successful. We thank Dr. John Hall for assistance with statistical analysis and Paula Haag, Karen Bedford, Darrell-lee Mckenzie, Marjorie King and Rod Hocking for technical assistance.

\section{References}

[1] Snowdon A.L., A color atlas of post-harvest diseases and disorders of fruits and vegetables, Vol. 1: General introduction \& Fruits, CRC Press, Inc., Boca Raton, Florida, USA, 1990.
[2] Sholberg P., Postharvest handling of pome fruits, soft fruits, and grapes. Agriculture Canada, Publication 1768E, Ottawa, Canada, 2000, Available as an electronic publication: http://res2agr,ca/parc-crapac/english/3electronic_publications/phhandbook/default.htm

[3] Archibald S.O., Winter C.K., Pesticides in our food. Assessing the risks, in: Winter C.K., Seiber J.N., Nuckton C.F. (Eds), Chemicals in the human food chain, Van Nostrand Reinhold, New York, USA, 1990.

[4] Sholberg P.L., Haag P.D., Incidence of postharvest pathogens of stored apples in British Columbia, Can. J. Plant Pathol. 18 (1996) 81-85.

[5] Rosenberger D.A., Blue mold, in: Jones A.L., Aldwinckle H.S. (Eds), Compendium of apple and pear diseases, APS Press, St. Paul, USA, 1990.

[6] Eckert J.W., Dynamics of benzimidazoleresistant Penicillia in the development of postharvest decays of citrus and pome fruits, in: Delp C.J. (Ed.), Fungicide resistance in North America, APS Press, St. Paul, USA, 1988.

[7] Bond E.J., Chemical control of stored grain insects and mites, in: Sinha R.N., Muir W.E. (Eds), Grain storage: part of a system, The AVI Publishing Co., Inc., Wesport, CT, USA, 1973.

[8] Eckert J.W., Ogawa J.M., The chemical control of postharvest diseases: deciduous fruits, berries, vegetables and root/tuber crops, Ann. Rev. Phytopathol. 26 (1988) 433-469.

[9] Stadelbacher G.J., Prasad K., Postharvest decay control of apple by acetaldehyde vapor, J. Am. Soc. Hortic. Sci. 99 (1974) 364-368.

[10] Mattheis J.P., Roberts R.G., Fumigation of sweet cherry (Prunus avium 'Bing') fruit with low molecular weight aldehydes for postharvest decay control, Plant Dis. 77 (1993) 810-814.

[11] Yuen C.M.C., Paton J.E., Hanawati R., Shen L.Q., Effects of ethanol, acetaldehyde and ethyl formate vapour on growth of Penicillium italicum and $P$. digitatum on oranges, J. Hortic. Sci. 70 (1995) 81-84.

[12] Agreda V.H., Zoeller J.R., Acetic acid and its derivatives, Marcel Dekker, Inc., New York, USA, 1993.

[13] Sholberg P.L., Gaunce A.P., Fumigation of fruit with acetic acid to prevent postharvest decay, HortScience 30 (1995) 1271-1275. 
[14] Sholberg P.L., Gaunce A.P., Fumigation of stone fruit with acetic acid to control postharvest decay, Crop Prot. 15 (1996) 681-686.

[15] Chu C.L., Liu W.T., Zhou T., Tsao R., Control of postharvest gray mold rot of modified atmosphere packaged sweet cherries by fumigation with thymol and acetic acid, Can. J. Plant Sci. 79 (1999) 685-689.

[16] Sholberg P.L., Fumigation of fruit with shortchain organic acids to reduce the potential of postharvest decay, Plant Dis. 80 (1998) 689-693.

[17] Sholberg P.L., Reynolds A.G., Gaunce A.P., Fumigation of table grapes with acetic acid to prevent postharvest decay, Plant Dis. 80 (1996) 1425-1428.

[18] Moyls A.L., Sholberg P.L., Gaunce A.P., Modified-atmosphere packaging of grapes and strawberries fumigated with acetic acid, HortScience 31 (1996) 414-416.

[19] Sholberg P.L., Delaquis P.J., Moyls A.L., Use of acetic acid fumigation to reduce the potential for decay in harvested crops, Recent Res. Dev. Plant Pathol. 2 (1998) 31-42.

[20] Csima A., Reid D.B.W., Table for testing the significance of the difference between proportions, University of Toronto, Department of Epidemiology and Biometrics, Toronto, Canada, 1961.

[21] Rosenberger D.A., Wickow D.T., Korjagin V.A., Rondinaro S.M., Pathogenicity and benzimidazole resistance in Penicillium species recovered from flotation tanks in apple packinghouses, Plant Dis. 75 (1991) 712-715.

[22] Spotts R.A., Cervantes L.A., Populations, pathogenicity, and benomyl resistance of Botrytis spp., Penicillium spp., and Mucor piriformis in packinghouses, Plant Dis. 70 (1986) 106-108.

[23] Bertrand P.F., Saulie-Carter J.L., The occurrence of benomyl-tolerant strains of Penicillium expansum and Botrytis cinerea in the Mid-Columbia region of Oregon and Washington, Plant Dis. Rep. 62 (1978) 302-305.

[24] Sholberg P., Shephard T., Moyls L., A novel detection system for continuous monitoring of acetic acid vapour concentrations for decay control, (Abstract) Can. Inst. Food Sci. Tech. Annu. Meet., Kelowna, British Columbia, Canada, 1999.

[25] Moss M.O., The occurrence and significance of mould toxins (mycotoxins) in food, Food Sci. Technol. Today 9 (1995) 35-38.

\section{Fumigación con vapor de ácido acético para controlar el deterioro de manzanas almacenadas.}

Resumen - Introducción. Las manzanas están potencialmente expuestas a la marchitez azul del manzano causada por Penicillium expansum si se almacenan a $1{ }^{\circ} \mathrm{C}$ durante 3 meses o más o si sufren daños durante la manipulación. Los resultados de ensayos efectuados con manzanas contaminadas por conidios de P. expansum y fumigadas en un local reducido con vapor de ácido acético (AA) mostraron que los frutos esterilizados podían deteriorarse menos sin que su calidad se viera alterada. El objetivo de este trabajo ha sido determinar si era posible proteger cantidades mayores de manzanas contra dichos deterioros tras almacenamiento y/o después de las heridas tratándolas con vapor de AA. Se trataba, asimismo, de determinar si la fumigación afectaba a la calidad y al aroma de las manzanas tratadas. Material y métodos. Se cosecharon manzanas de diferentes cultivares en la fase de madurez comercial y se utilizaron en pruebas de fumigación con AA. Se fumigaron manzanas, artificial o naturalmente contaminadas con conidios de $\mathrm{P}$. expansum, con vapor de AA en una cámara de $1 \mathrm{~m}^{3}$, estanca al gas, a $10{ }^{\circ} \mathrm{C}$ durante $1 \mathrm{~h}$ a $24 \mathrm{~h}$ o sumergidas en una solución de tiabendazol a $450 \mu \mathrm{g} \times \mathrm{L}^{-1}$. Los frutos fumigados fueron dañados y, posteriormente, se evaluó su deterioro tras una semana a $20^{\circ} \mathrm{C}$, o bien almacenados a $1{ }^{\circ} \mathrm{C}$ durante 3 meses o más y, seguidamente, se evaluó su estado. Se estimó, entonces, la calidad de las manzanas. Resultados. Las manzanas naturalmente contaminadas con Penicillium spp., almacenadas al aire a $1{ }^{\circ} \mathrm{C}$ y tratadas con vapor de AA sufrieron la mitad de daños que los frutos testigos. En otro experimento, la fumigación con AA fue tan eficaz como el tiabendazol para reducir la marchitez. La fumigación con AA redujo el deterioro de los frutos tras almacenamiento durante 3 meses y un segundo tratamiento con 
P.L. Sholberg et al.

AA disminuyó la infección de las heridas en las mismas manzanas. La fumigación con AA efectuada antes del almacenamiento no afectó a la calidad de las manzanas. Discusión. Las fumigaciones con vapor de AA son, por ló tanto, potencialmente muy interesantes para reducir el deterioro de las manzanas almacenadas. Estas fumigaciones podrían reemplazar a los fungicidas sintéticos para controlar la marchitez azul del manzano.

Canada / Malus (frutas) / enfermedades postcosecha / enfermedades fungosas / Penicillium ex pansum / control de enfermedades / métodos de control / ácido acético / fumigación / tiabendazol / calidad

To access this journal online: www.edpsciences.org 